Article

\title{
New Data on the Biology and Fisheries of the Threatened Palinurus elephas (Fabricius, 1787) (Decapoda, Achelata, Palinuridae) from the North-West Aegean Sea, Greece
}

\author{
Thodoros E. Kampouris ${ }^{1, *(1)}$, Drosos Koutsoubas ${ }^{1}$, Debora Milenkova ${ }^{2}$, Georgios Economidis ${ }^{3}$, \\ Stylianos Tamvakidis ${ }^{4}$ and Ioannis E. Batjakas ${ }^{1}$ \\ 1 Department of Marine Sciences, School of the Environment, University of the Aegean, University Hill, \\ Mytilene, 81100 Lesvos Island, Greece; drosos@aegean.gr (D.K.); jbatzakas@marine.aegean.gr (I.E.B.) \\ 218 Ashby Cres, Glasgow, Scotland G13 2NT, UK; debmilenkova@gmail.com \\ 3 Fisheries Department, Directorate of Agricultural Economy and Fisheries, Region of Central Macedonia, \\ 64 26th October Str., 54627 Thessaloniki, Greece; G.Ekonomidis@pkm.gov.gr \\ 4 Department of Farming and Fisheries, Directorate of Agricultural Affairs of Central Macedonia, \\ Decentralized Administration of Macedonia-Thrace, Navarinou 28 and Karaoliand Dimitriou, \\ 55131 Thessaloniki, Greece; day-km@damt.gov.gr \\ * Correspondence: mard16012@marine.aegean.gr
}

Received: 17 June 2020; Accepted: 23 August 2020; Published: 26 August 2020

\begin{abstract}
The European spiny lobster Palinurus elephas is a vulnerable species that inhabits and is harvested in the Mediterranean Sea and the adjacent Atlantic waters. The fisheries associated with the spiny lobster are mainly conducted with tangle nets, trammel nets, pots, and creels. The fishing pressure has greatly reduced their numbers, changing them from a common shallow coastal species to a largely remnant population. The relative research on the species' biology and fisheries from the eastern Mediterranean Sea is almost absent. The fishery along the Chalkidiki Peninsula, Greece, is multispecies, and fishing is conducted by a small number of artisanal fishermen mainly using trammel nets. The lobster stock — both spiny and clawed lobsters-declined significantly during the late 1980s and early 1990s, later than most cases in the Mediterranean Sea. However, data regarding the nature and status of the fishery associated with the spiny lobster in Greece are lacking. Data regarding the characteristics of the spiny regional fishery were obtained by interviews and questionnaires. Additionally, fishery surveys were conducted during the main lobster fishing season from 1 May 2017 to 31 August 2017. Sixteen species were identified (15 finfish species and one invertebrate species) as targeted. In total, 79 spiny lobsters were sampled in this study; the population's sex ratio significantly diverts from the theoretical 1:1 $\left(\chi^{2}=4.57 ; p<0.05\right)$, and males were dominant. Both male and female individuals demonstrate negative allometric growth profiles. In addition, no significant differences were observed between sexes. In Greece, thus far, the knowledge and information are sporadic, limited, and/or species-specific, most of which regard finfish fisheries. Furthermore, the national legislation is rather complicated —or too generalized - thus creating great uncertainties. The in-depth knowledge and experience of fishermen should be further acknowledged and utilized, and wider collaborations among scientists, practitioners, and policy-makers should be established. The present study poses some thoughts on the effectiveness of the recent EU Landing Obligation and its contribution to the potential restoration of the species.
\end{abstract}

Keywords: spiny lobster; artisanal fisheries; threatened species; eastern Mediterranean 


\section{Introduction}

Globally, six species compose the genus Palinurus, three of which are found in the Mediterranean Sea and the adjacent Atlantic waters (P. elephas, P. mauritanicus, and P. charlestoni), with both morphological and molecular (mtDNA) differences [1]. All species are exploited and are thus included in the International Union for Conservation of Nature (IUCN) Red List of Threatened Species [2-4]. To date, three alien and rare lobster species have been reported in the Mediterranean Sea and along the east Atlantic coast: the rare Panulirus regius de Brito Capello, 1864 [5], the American lobster Homarus americanus H. Milne Edwards, 1837 [6] and the Lessepsian Panulirus ornatus (Fabricius, 1798) [7].

Palinurus elephas (Fabricius, 1787) is found across the Mediterranean Sea, in the east Atlantic from North Africa to Scotland, U.K. (Hebrides and Orkney Isles) [8,9], but only in Scotland is it considered rare [10,11]. Records from Scandinavia should be considered as doubtful, since recent records of the species have not been reported [12,13]. It is the only spiny lobster species in the eastern Mediterranean Sea, dwelling in shallow waters up to $200 \mathrm{~m}$, commonly found in hard substrates [1,14], though several individuals have been observed in coarse bottoms (i.e., "scuddy" grounds) [10], sand beds [15], and mixed sediments [16]. The European spiny lobster is classified by IUCN as "Vulnerable" mainly due to its continuous overfishing [4]. Data of the relevant fisheries are very scarce and are usually local or regional, making it unclear when fishermen began to fish beyond sustainable limits, though non-selective netting is negatively impacting population size. Older studies clearly demonstrated that the species used to be abundant in the east Atlantic Ocean and the Mediterranean Sea. For instance, Bonnier [17] characterized the species as "very common" and stated that the most common fishing depths ranged from 80 to $100 \mathrm{~m}$. Ritchie [10] stated that the species "is very common on the rocky parts of the southern and western coasts of France" and that it occurs "in great numbers and from whence it is brought in considerable quantities to the London market." The south and west coasts of Ireland used to be important fishing grounds for spiny lobster during the 20th century [13]. Regarding Mediterranean waters, Selbie [13] characterized the species as "extremely abundant" in the western basin-off the coasts of Corsica, Sardinia, Tunis and Balearic Islands and the relative fishery in Corsica and Italy as a "thriving industry". The same author also stated that spiny lobsters occurred in "large numbers" in the Aegean and Adriatic Seas. Over and above, lobster fisheries were described as not well developed [13,18], and the species was described as "targeted" in Corsica in the 1980s [19].

Nowadays, predominantly in Mediterranean countries, the first sale price of the species might reach as high as $120 \mathrm{EUR} / \mathrm{kg}^{-1}$, but despite its huge economic value, European spiny lobster supports only a peripheral fishery and it is considered as a by-catch species for more than 100 finfish fisheries [1,14,20]. Until the 1960s or 1970s, spiny lobsters were caught mainly by traps and pots and occasionally (e.g., Cornwall) by SCUBA diving (e.g., [21-24]). After this period, there was an important change in fishing gear, from traps and pots to the gradual establishment of trammel and tangle nets. This change, in combination with the instalment of new technologies, better materials in fishing equipment, and eventually, the increase in fishing effort, are the main reasons of the collapse of the spiny lobster population [25] (but see [1] for details regarding the spiny lobster fishery in European waters). A summary of the spiny lobster fishery status, such as the involved vessels, the gear used, and fishery management, is provided in Table 1. There are only few and sparse available data regarding the spiny lobster fishery in Aegean Sea. In Greek seas, lobsters (i.e., P. elephas, Scyllarides latus (Latreille, 1803) and Homarus gammarus (Linnaeus, 1758) are considered a delicacy and are highly priced (30-90 EUR/ $\mathrm{kg}^{-1}$ ) (Kampouris, pers. com.). All lobster species are considered as by-catch for an unknown number of artisanal vessels. Until the early 1970s, lobster fishing in Greece was conducted with low-technology gear and tools [26]. The main fishing grounds were the wide areas of Agios Efstratios Island in the north-east Aegean, Skyros Island in the north-west Aegean, and Kerkira (Corfu) Island in the Ionian Sea [27]. Relative data from the Thracian Sea indicate that during the two-year period between 1997 and 1999, the regional catch was $1682.5 \mathrm{~kg}$ and corresponded to $0.2 \%$ of the total catch [28]. The Hellenic spiny lobster fishery has the same issues as most artisanal Mediterranean fisheries: most individuals are sold directly to consumers, hotels, or restaurants. Although monitoring and management plans are 
lacking, there are some specific fishery restrictions concerning all lobster species (i.e., spiny, clawed, and slipper lobsters) in general, such as: (1) fishing is prohibited from 1 September to 31 December; (2) the minimum landing size is $90 \mathrm{~mm}$ of carapace length or $240 \mathrm{~mm}$ of body length; (3) the minimum landing weight is $420 \mathrm{~g}$; and (4) the prohibition of landing berried females [20]. Several vessels are active along the Turkish Aegean coasts from Saros Bay (south) to Ayvalik and Foça. These vessels use trammel nets with a mesh size ranging from 85 to $170 \mathrm{~mm}$, with a total length of $6 \mathrm{~km}$. Usually, these vessels range in length from 20 to $25 \mathrm{~m}$ [29] (see Table 1).

Table 1. Status of the spiny lobster fishery regulations across its distribution, modified by [1,20].

\begin{tabular}{|c|c|c|c|c|c|}
\hline Country & Vessels Involved & Past Fishing Gear & Present Fishing Gear & Fishing Period & Management Measures \\
\hline \multirow[b]{2}{*}{ Ireland } & \multirow[b]{2}{*}{$20-25$ vessels } & \multirow{2}{*}{$\begin{array}{l}\text { Traps and diving } \\
\text { (until 1970) }\end{array}$} & \multirow[b]{2}{*}{ Trammel nets } & \multirow[b]{2}{*}{ May-September } & MLS $110 \mathrm{~mm}$ CL \\
\hline & & & & & $\begin{array}{l}\text { Area closure where netting is } \\
\text { prohibited }\end{array}$ \\
\hline \multirow{3}{*}{ The U.K. } & \multirow{3}{*}{ Unknown } & \multirow{3}{*}{$\begin{array}{l}\text { Potting, diving, and } \\
\text { use of creels (traps) } \\
\text { (until 1960-1970) }\end{array}$} & \multirow{3}{*}{$\begin{array}{l}\text { Trammel and tangle } \\
\text { nets, as well as creels in } \\
\text { some areas of Scotland }\end{array}$} & \multirow{3}{*}{ May-August } & MLS $87 \mathrm{CL}, 90 \mathrm{~mm}$ in Shetland \\
\hline & & & & & MLS $155 \mathrm{~mm}$ for female lobsters \\
\hline & & & & & Some areas re-closed to potting \\
\hline France (Atlantic coast) & Unknown & $\begin{array}{l}\text { Potting and diving } \\
\text { (until 1960-1970) }\end{array}$ & $\begin{array}{l}\text { Trammel nets }(\mathrm{mesh} \\
\text { size } 240-320 \mathrm{~mm})\end{array}$ & April-November & MLS95 $\mathrm{mm}$ CL or $23 \mathrm{~cm}$ TL \\
\hline \multirow[b]{2}{*}{ France (Corsica) } & \multirow[b]{2}{*}{200 vessels } & \multirow{2}{*}{$\begin{array}{l}\text { Nylon trammel nets } \\
\text { and potting } \\
\text { (until 1960-1970) }\end{array}$} & \multirow{2}{*}{$\begin{array}{l}\text { Trammel nets }(\mathrm{mesh} \\
\text { size } 125-160 \mathrm{~mm})\end{array}$} & \multirow[b]{2}{*}{ April-August } & MLS $80 \mathrm{~mm}$ CL \\
\hline & & & & & $\begin{array}{l}\text { Fishing is prohibited from } \\
\text { September to March }\end{array}$ \\
\hline \multirow[b]{2}{*}{ Portugal } & \multirow[b]{2}{*}{40 vessels } & \multirow{2}{*}{$\begin{array}{l}\text { Trammel, tangle, and } \\
\text { gill nets }\end{array}$} & \multirow{2}{*}{$\begin{array}{l}\text { Trammel, tangle, and } \\
\text { gill nets }\end{array}$} & \multirow{2}{*}{$\begin{array}{l}\text { Spring and } \\
\text { summer }\end{array}$} & MLS 95 mm CL \\
\hline & & & & & $\begin{array}{l}\text { Landing ovigerous females is } \\
\text { prohibited }\end{array}$ \\
\hline \multirow{4}{*}{$\begin{array}{c}\text { Spain } \\
\text { (Mediterranean coast) }\end{array}$} & \multirow{4}{*}{$>600$ vessels } & \multirow{4}{*}{$\begin{array}{c}\text { Potting } \\
\text { (until 1960-1970) }\end{array}$} & \multirow{4}{*}{$\begin{array}{l}\text { Trammel nets; some } \\
\text { traps still operate in } \\
\text { the Balearic Islands }\end{array}$} & \multirow{4}{*}{ March-August } & MLS $80 \mathrm{~mm} \mathrm{CL}$ \\
\hline & & & & & $\begin{array}{l}\text { Fishing is prohibited from } \\
\text { September to February }\end{array}$ \\
\hline & & & & & Limitations on fishing gear \\
\hline & & & & & $\begin{array}{l}\text { Landing ovigerous females is } \\
\text { prohibited }\end{array}$ \\
\hline Morocco & Unknown & Potting and netting & Potting and netting & Unknown & MLS $170 \mathrm{~mm}$ TL \\
\hline \multirow{3}{*}{ Tunisia } & \multirow{3}{*}{56 vessels } & \multirow{3}{*}{ Unknown } & \multirow{3}{*}{ Trammel nets } & \multirow{3}{*}{ March-August } & MLS $67 \mathrm{~mm} \mathrm{CL}$ \\
\hline & & & & & $\begin{array}{l}\text { Fishing is prohibited from } \\
\text { September to February }\end{array}$ \\
\hline & & & & & $\begin{array}{l}\text { Landing ovigerous females is } \\
\text { prohibited }\end{array}$ \\
\hline \multirow{3}{*}{ Italy } & & & & & MLS107 mm CL \\
\hline & Unknown & Pots and traps & Trammel nets & $\begin{array}{l}\text { May until } \\
\text { unknown }\end{array}$ & $\begin{array}{l}\text { Fishing is prohibited from } \\
\text { January to April }\end{array}$ \\
\hline & & & & & $\begin{array}{l}\text { Landing ovigerous females is } \\
\text { prohibited }\end{array}$ \\
\hline & & & Trammol nets (mesh & & MLS240 $\mathrm{mm} \mathrm{TL}$ \\
\hline Croatia & Unknown & Unknown & $\begin{array}{l}\text { size } 80 \mathrm{~mm} \text { ) and gill } \\
\text { nets (mesh size }\end{array}$ & $\begin{array}{l}\text { May until } \\
\text { unknown }\end{array}$ & $\begin{array}{l}\text { Fishing is prohibited from } \\
\text { October to April }\end{array}$ \\
\hline & & & $120 \mathrm{~mm})$ & & $\begin{array}{l}\text { Landing ovigerous females is } \\
\text { prohibited }\end{array}$ \\
\hline & & & & & MLS240 mm TL \\
\hline & & & Trammel, tangle, and & & MLW $<420 \mathrm{~g}$ \\
\hline Greece & Unknown & $\begin{array}{l}\text { Potting and netting } \\
\quad \text { (until 1980) }\end{array}$ & $\begin{array}{l}\text { gill nets, as well as } \\
\text { potting }\end{array}$ & April-August & $\begin{array}{l}\text { Fishing is prohibited from } \\
\text { September to December }\end{array}$ \\
\hline & & & & & $\begin{array}{l}\text { Landing ovigerous females is } \\
\text { prohibited }\end{array}$ \\
\hline Turkey & Unknown & Unknown & $\begin{array}{l}\text { Trammel nets }(\mathrm{mesh} \\
\text { size } 85-170 \mathrm{~mm})\end{array}$ & April-June & Unknown \\
\hline
\end{tabular}

MLS, minimum landing size; $C L$, carapace length; TL, total length; MLW, minimum landing weight.

Length-weight (L-W) and/or length-length ( $\mathrm{L}-\mathrm{L}$ ) relationships are often used to study population characteristics of many crustacean species. Moreover, these equations contribute to understanding the life history of different species [30], such as changes during growth [31] or variability amongst populations of the same species [32], that may hide genetic diversity. Additionally, these relationships set the basis for population modelling [33] and are therefore quite useful for studying biology at the fishery level [34]. Furthermore, morphometric studies are useful in ecological research, since 
populations of the same species may exhibit morphological differences that reflect adaptations under regional environmental conditions [35].

The present study aimed to review (in brief) the historic distribution and abundance of P. elephas. Additionally, it presents, for the first-time, data on the fishery and biology of the threatened spiny lobster from the Chalkidiki Peninsula and the Thermaikos Gulf. Our study is among the few recent ones regarding this species in the Mediterranean Sea.

\section{Materials and Methods}

\subsection{Survey Area}

The Thermaikos Gulf is in the north-western Aegean Sea (Figure 1). It is the largest gulf (covering and area of about $5100 \mathrm{~km}^{2}$ ) and is one of the most productive parts of the eastern Mediterranean basin [36] that supports the most important fishing activity in Hellenic waters [37]. The oceanographic characteristics of the Thermaikos Gulf demonstrate seasonality. The significant forces that form its ecological status are the water exchanges from/to the Aegean Sea and the riverine fluxes of freshwater from several rivers [38]. The Thermaikos Gulf has little depth variation and it is dominated by soft sediments. These have an impact on the resuspension generally [39] and are several times higher in comparison to the contribution from the major rivers in the area [39]. The gulf receives approximately $120,000 \mathrm{~m}^{3}$ day $^{-1}$ of sewage from the city of Thessaloniki and $25,000 \mathrm{~m}^{3}$ day $^{-1}$ of industrial discharge [40]. The caramote prawn Penaeus kerathurus (Forskål, 1775) and the pink shrimp Parapenaeus longirostris (Lucas, 1846) are the two main decapod species that are believed to be exploited in the Thermaikos Gulf [41]. Furthermore, the invasive blue crab Callinectes sapidus (Rathbun, 1896) is fished and some quantities are, mainly, exported [42].

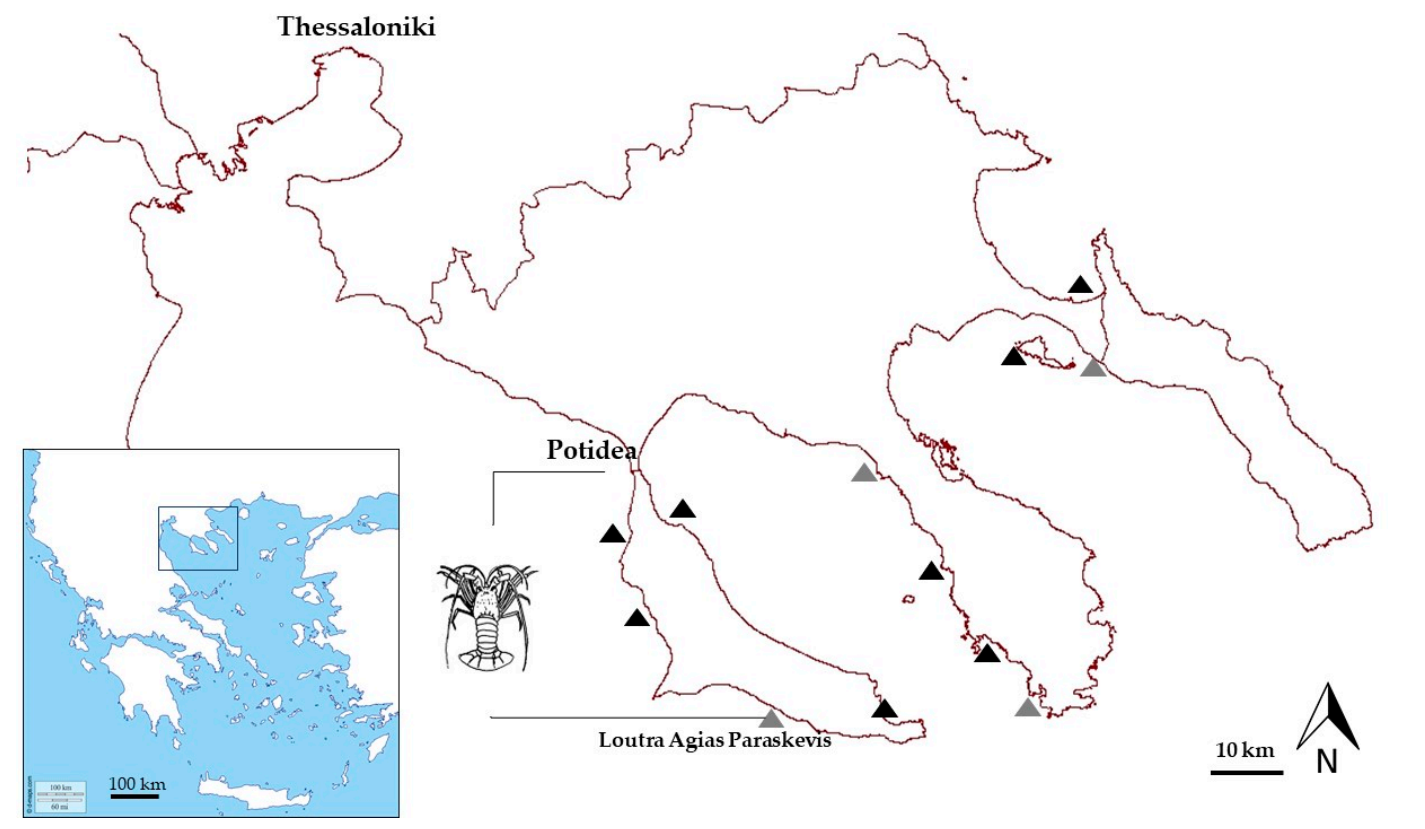

Figure 1. The study area. The fishing operations are marked with the lobster icon. Black triangles indicate the locations that successful interviews with fishermen were undertaken, while grey triangles represent the unsuccessful ones.

\subsection{Sampling}

Fishing took place overnight every 15 days, during the main lobster fishing season from 1 May 2017 to 31 August 2017. Sampling took place between Potidaia $\left(40^{\circ} 11^{\prime} 17.9^{\prime \prime} \mathrm{N} 23^{\circ} 19^{\prime} 06.0^{\prime \prime} \mathrm{E}\right)$ and Loutra Agias Paraskevis ( $39^{\circ} 55^{\prime} 02.3^{\prime \prime}$ N 2335'21.2" E). The soak time was $12-14$ h depending on weather conditions. Trammel nets of $2-5 \mathrm{~km}$ in length were used over hard bottoms. The mesh size, 
knot to knot, ranged from 35 to $50 \mathrm{~mm}$. Small floats were placed equidistantly along the net's whole length to prevent entanglement, while weights were used to keep it close to the bottom. A plastic 9-m-long artisanal fishing vessel was used, and the fishing depth ranged from 45 to $90 \mathrm{~m}$. All spiny lobster individuals of legal size were measured on board and were then sold, while all undersized individuals were released (see discussion). The targeted species were identified at the species level.

\subsection{Interviews and Questionnaires}

The systematic interviews and the relative questions were based on earlier studies, mainly regarding the Caribbean lobster Panulirus argus (Latreille, 1804) fishery [43], the red spiny lobster Panulirus penicillatus (Olivier, 1791) fishery at Galapagos [44,45], the spiny lobster fishery Panulirus spp. in Sumatra [46], and Australia's multispecies prawn fishery [47], since they present advantages and similarities with the Mediterranean artisanal spiny lobster fisheries. In terms of advantages, spiny lobsters in the Caribbean Sea and Galapagos Archipelagos are well studied, and are therefore quite useful in studies such as the present one. Additionally, in the Galapagos, Caribbean, and Sumatra, spiny lobster fisheries are mostly artisanal or of small scale, multispecies, utilizing different fishing gear, and an important population decline was observed by 1960-1970. However, other studies regarding European waters were also consulted [48].

Unfortunately, some fishermen provided misleading or false data and statements, or they were not eager to discuss at all, openly expressing their mistrust of scientists in general. These responders were classified as "unsuccessful"-please see Figure 1. Four groups of questions were asked. The first one was related to the fishing communities and the relative demographics. The second group of questions regarded the fishing equipment, gear, and methodology used (vessel, fishing gear, crew number, etc.) (Table 2). The third was associated with the characteristics of the fishery, such as distance from ports, depth, and soaking time. The last group concerned the economic nature and profitability of the fishery in the study area. In addition, the main targeted species were determined (Table 3). 
Table 2. Characteristics of the spiny lobster fishery along the Chalkidiki Peninsula and its status based on interviews and questionnaires.

\begin{tabular}{|c|c|c|c|c|c|c|c|c|}
\hline \multicolumn{9}{|c|}{ Fishermen Demographics } \\
\hline & F1 & F2 & F3 & F4 & F5 & F6 & F7 & F8 \\
\hline Age (in 2017) & 45 years & 37 years & 63 years & 65 years & 38 years & 66 years & 48 years & 42 years \\
\hline Fishing Experience & 30 years & 21 years & 53 years & 52 years & 28 years & 50 years & 33 years & 28 years \\
\hline \multicolumn{9}{|c|}{ Fishing Vessel and Gear } \\
\hline Vessel Length & $\begin{array}{c}7 \mathrm{~m} \\
12 \mathrm{~m}^{*}\end{array}$ & $10.5 \mathrm{~m}$ & $10.5 \mathrm{~m}$ & $6 \mathrm{~m}$ & $7 \mathrm{~m}$ & $15 \mathrm{~m}$ & $9.5 \mathrm{~m}$ & $8 \mathrm{~m}$ \\
\hline Crew Number & 2 persons & 2 persons & 2 persons & 2 persons & 1 person & 3 persons & 2 persons & 2 persons \\
\hline Vessel Material & Wooden & Plastic & Plastic & Wooden & Plastic & Plastic & Plastic & Plastic \\
\hline Vessel Horsepower & $35 \mathrm{HP}$ & $45 \mathrm{HP}$ & $45 \mathrm{HP}$ & $30 \mathrm{HP}$ & $15 \mathrm{HP}$ & $40 \mathrm{HP}$ & $25 \mathrm{HP}$ & $25 \mathrm{HP}$ \\
\hline \multirow{3}{*}{ Gear Type } & \multirow{3}{*}{ Trammel nets } & \multirow{3}{*}{ Trammel nets } & \multirow{3}{*}{ Trammel nets } & \multirow{3}{*}{ Trammel nets } & \multirow{3}{*}{ Trammel nets } & Trammel nets & \multirow{3}{*}{ Trammel nets } & Trammel nets \\
\hline & & & & & & Creels & & \multirow{2}{*}{ Creels } \\
\hline & & & & & & $\begin{array}{c}\text { Long line } \\
\text { (very rarely) }\end{array}$ & & \\
\hline Net Length & $1-5 \mathrm{~km}$ & $2-4 \mathrm{~km}$ & $2-5 \mathrm{~km}$ & $5 \mathrm{~km}$ & $3-6.5 \mathrm{~km}$ & $1.4 \mathrm{~km}$ & $600 \mathrm{~m}-1.5 \mathrm{~km}$ & $3-5 \mathrm{~km}$ \\
\hline Mesh Size (Knot to Knot) & $30-40 \mathrm{~mm}$ & $35-50 \mathrm{~mm}$ & $35-50 \mathrm{~mm}$ & $25-35 \mathrm{~mm}$ & $40-50 \mathrm{~mm}$ & $32 \mathrm{~mm}$ & $40-45 \mathrm{~mm}$ & $32-50 \mathrm{~mm}$ \\
\hline \multicolumn{9}{|c|}{ Fishery Characteristics } \\
\hline Distance from Ports & $1-8 \mathrm{~h}$ & $1-10 \mathrm{~h}$ & $1-10 \mathrm{~h}$ & $1-2 \mathrm{~h}$ & $1-10 \mathrm{~h}$ & $1 \mathrm{~h}$ & $1-1.5 \mathrm{~h}$ & $1-3 \mathrm{~h}$ \\
\hline Soak time & $12-14 \mathrm{~h}$ & $14-16 \mathrm{~h}$ & $14-16 \mathrm{~h}$ & $10-20 \mathrm{~h}$ & $12-14 \mathrm{~h}$ & $12-16 \mathrm{~h}$ & $10-12 \mathrm{~h}$ & $12-14 \mathrm{~h}$ \\
\hline Effective Fishing Hours & Late night-before sunrise & $\begin{array}{l}\text { Late night-before } \\
\text { sunrise }\end{array}$ & $\begin{array}{l}\text { Late night-before } \\
\text { sunrise }\end{array}$ & Early morning & Early morning & Night & $\begin{array}{l}\text { Late night-before } \\
\text { sunrise }\end{array}$ & Early morning \\
\hline Fishing Depth & $60-100 \mathrm{~m}$ & $30-90 \mathrm{~m}$ & $30-90 \mathrm{~m}$ & $20-110 \mathrm{~m}$ & $40-110 \mathrm{~m}$ & $35-130 \mathrm{~m}$ & $80-90 \mathrm{~m}$ & $90 \mathrm{~m}$ \\
\hline Fishing Season & April-August & March-August & March-August & March-May & April-August & March-August & March-August & March-August \\
\hline \multirow{2}{*}{ Catches per Season } & $\begin{array}{c}1-2 \text { individuals } \\
\text { (April-June) }\end{array}$ & \multirow{2}{*}{$\begin{array}{l}2-11 \mathrm{~kg} \text { per } \\
\text { deployment }\end{array}$} & \multirow{2}{*}{$\begin{array}{l}2-11 \mathrm{~kg} \text { per } \\
\text { deployment }\end{array}$} & \multirow{2}{*}{ No specific data } & \multirow{2}{*}{$\begin{array}{c}2-5 \mathrm{~kg} \\
\text { per deployment }\end{array}$} & \multirow{2}{*}{$\begin{array}{c}1-5 \mathrm{~kg} \\
\text { per deployment }\end{array}$} & \multirow{2}{*}{$\begin{array}{c}1-10 \mathrm{~kg} \\
\text { per deployment }\end{array}$} & \multirow{2}{*}{ No specific data } \\
\hline & $15 \mathrm{~kg}$ (July-August) & & & & & & & \\
\hline \multicolumn{9}{|c|}{ Economic Data } \\
\hline Wholesale Price & 30-45 EUR/kg & 30-40 EUR/kg & 30-40 EUR/kg & No data & 30-35 EUR/kg & $45-50$ EUR/kg & 35-40 EUR/kg & 35-45 EUR/kg \\
\hline Retail Price & $60 \mathrm{EUR} / \mathrm{kg}$ & - & - & No data & 60-90 EUR/kg & - & 60-120 EUR/kg & 60-90 EUR/kg \\
\hline
\end{tabular}


Table 3. Targeted species associated with the spiny lobster fishery along the Chalkidiki Peninsula based on interviews and questionnaires.

\begin{tabular}{|c|c|c|c|c|c|c|c|c|}
\hline \multicolumn{9}{|c|}{ Targeted Species } \\
\hline Species & F1 & F2 & F3 & F4 & F5 & F6 & F7 & F8 \\
\hline \multicolumn{9}{|c|}{ Sparidae } \\
\hline Diplodus sargus (Linnaeus, 1758) & Y & $\mathrm{Y}$ & $\mathrm{Y}$ & $\mathrm{Y}$ & $\mathrm{Y}$ & $\mathrm{Y}$ & $\mathrm{Y}$ & $\mathrm{Y}$ \\
\hline Diplodus vulgaris (Geoffroy Saint-Hilaire, 1817) & $\mathrm{Y}$ & $\mathrm{Y}$ & $\mathrm{Y}$ & $\mathrm{Y}$ & Y & Y & $\mathrm{Y}$ & $\mathrm{Y}$ \\
\hline Diplodus puntazzo (Walbaum, 1792) & $\mathrm{Y}$ & $\mathrm{Y}$ & $\mathrm{Y}$ & Y & Y & Y & $\mathrm{Y}$ & Y \\
\hline Spondyliosoma cantharus (Linnaeus, 1758) & $\mathrm{Y}$ & $\mathrm{Y}$ & $\mathrm{Y}$ & $\mathrm{N}$ & $\mathrm{Y}$ & Y & $\mathrm{Y}$ & $\mathrm{Y}$ \\
\hline Pagellus erythrinus (Linnaeus, 1758) & Y & $\mathrm{Y}$ & $\mathrm{Y}$ & $\mathrm{N}$ & $\mathrm{N}$ & Y & $\mathrm{Y}$ & Y \\
\hline Pagrus pagrus (Linnaeus, 1758) & Y & $\mathrm{Y}$ & Y & $\mathrm{Y}$ & Y & Y & Y & Y \\
\hline Dentex dentex (Linnaeus, 1758) & $\mathrm{Y}$ & $\mathrm{Y}$ & $\mathrm{Y}$ & $\mathrm{Y}$ & $\mathrm{Y}$ & $\mathrm{Y}$ & $\mathrm{Y}$ & $\mathrm{Y}$ \\
\hline Dentex gibbosus (Rafinesque, 1810) & Y & Y & $\mathrm{Y}$ & Y & Y & Y & $\mathrm{Y}$ & Y \\
\hline \multicolumn{9}{|c|}{ Scorpaenidae } \\
\hline Scorpaena elongata Cadenat, 1943 & Y & $\mathrm{Y}$ & Y & Y & $\mathrm{N}$ & $\mathrm{N}$ & Y & Y \\
\hline \multicolumn{9}{|c|}{ Triglidae } \\
\hline Chelidonichthys lucerna (Linnaeus, 1758) & $\mathrm{N}$ & $\mathrm{Y}$ & Y & $\mathrm{N}$ & $\mathrm{N}$ & $\mathrm{N}$ & $\mathrm{N}$ & $\mathrm{N}$ \\
\hline \multicolumn{9}{|c|}{ Lophiidae } \\
\hline Lophius piscatorius Linnaeus, 1758 & $\mathrm{~N}$ & $\mathrm{Y}$ & $\mathrm{Y}$ & $\mathrm{N}$ & $\mathrm{N}$ & $\mathrm{N}$ & $\mathrm{Y}$ & $\mathrm{N}$ \\
\hline Lophius budegasa Spinola, 1807 & $\mathrm{~N}$ & $\mathrm{Y}$ & $\mathrm{Y}$ & $\mathrm{N}$ & $\mathrm{N}$ & $\mathrm{N}$ & $\mathrm{Y}$ & $\mathrm{N}$ \\
\hline \multicolumn{9}{|c|}{ Sciaenidae } \\
\hline Sciaena umbra Linnaeus, 1758 & $\mathrm{~N}$ & $\mathrm{~N}$ & $\mathrm{~N}$ & $\mathrm{~N}$ & $\mathrm{Y}$ & $\mathrm{N}$ & $\mathrm{Y}$ & $\mathrm{Y}$ \\
\hline \multicolumn{9}{|c|}{ Serranidae } \\
\hline Epinephelus costae (Steindachner, 1878) & $\mathrm{N}$ & $\mathrm{N}$ & $\mathrm{N}$ & $\mathrm{N}$ & $\mathrm{N}$ & Y & $\mathrm{N}$ & $\mathrm{N}$ \\
\hline \multicolumn{9}{|c|}{ Labridae } \\
\hline Wrasses (Labrus sp.) & $\mathrm{N}$ & $\mathrm{N}$ & $\mathrm{N}$ & $\mathrm{N}$ & Y & $\mathrm{N}$ & $\mathrm{N}$ & $\mathrm{N}$ \\
\hline \multicolumn{9}{|c|}{ Nephropidae } \\
\hline Homarus gammarus (Linnaeus, 1758) & $\mathrm{Y}$ & $\mathrm{Y}$ & $\mathrm{Y}$ & $\mathrm{Y}$ & $\mathrm{Y}$ & Y & $\mathrm{Y}$ & $Y$ \\
\hline
\end{tabular}

\subsection{Morphometric Measurements}

All measurements were performed by the first author. The carapace length (CL) measurements were obtained according to Hepper, 1966 and Tidu et al., 2004 [49,50], from the posterior margin of the eye socket to the posterior end of the carapace. The carapace width $(\mathrm{CW})$ measurements followed the process of [51]. Moreover, the abdomen length (ABL) and abdomen width (ABW) were measured as described by [52]. All length and width measurements were obtained with a digital calliper, while measurements of wet weight $(\mathrm{W})$ were obtained, to the nearest gram, by using an electronic scale.

Given the fact that there are no available published data from the east Mediterranean Sea, the size grouping, regarding the frequency distribution, was selected by the authors based on the findings of the present study. In particular, the size grouping was based on the minimum, average, and maximum values of the sampling size along with the number of recorded individuals. The bin size of each class was selected based on the range of each measurement (CW, CL, ABW, ABL). The L-W relationships were expressed by the equation $W=a L^{b}$ or in its logarithmic form of $\log W=\log a+b \log L$, where $W$ is the weight; $\mathrm{L}$ is the $\mathrm{CW}, \mathrm{CL}, \mathrm{ABL}$, or ABW; $a$ is the intercept, and $b$ is the slope. The constants $a$ and $b$ were estimated by the linear regression from the logarithmically transformed data. The degree of association between length-weight variables was determined by the coefficient of determination $\left(r^{2}\right)$ of the linear regression. The types of allometric growth were determined by the values of constant $b$ ( $b<3$ negative allometry, $b=3$ isometry, and $b>3$ positive allometry) [53]. 


\subsection{Statistical Analyses}

The R Project [54] software was used to determine the allometric growth profiles and to produce the relative graphs. The sex ratio differences, based on the null hypothesis of a 1:1 population ratio, was assessed with chi-square $\left(\chi^{2}\right)$ analysis. Analysis of variance (ANOVA) used to assess the significance of linear regression [33]. Student's two-sample $t$-tests were used to assess potential differences between sexes regarding all morphometric characteristics.

\section{Results}

\subsection{Interviews and Questionnaires}

Eight fishermen were interviewed for the purpose of the present study. The average age of the fishermen (i.e., the skipper) was $50.5 \pm 11.9$ years and the average fishing experience was $36.9 \pm 12.7$ years. The average vessel length was $9.4 \pm 2.9 \mathrm{~m}$ and the crew number ranged from 1 (i.e., the skipper) to 3 . In most of the cases, the crew was strongly associated with the skipper (e.g., a family member). Both wooden and plastic vessels were used at the lobster fishery, and the average horsepower was $32.5 \pm 10.7 \mathrm{HP}$. The main gear used was trammel nets, but some (2/8) also used lobster creels. One interviewee said that spiny lobsters are very rarely caught using a long line. The length of the nets ranged from $600 \mathrm{~m}$ to $6.5 \mathrm{~km}$ and the average length was $3.2 \pm 1.9 \mathrm{~km}$, while the mesh size, knot to knot, ranged from 25 to $50 \mathrm{~mm}$ and the average size was $38.8 \pm 8.1 \mathrm{~mm}$. Usually, fishermen in the study area do not perform long fishing excursions, since they travel for $1-3 \mathrm{~h}$ to deploy their gear. Sometimes, when the demand is high, their trips may last up to $10 \mathrm{~h}$, deploying their gear in other regions (e.g., the Sporades islands). The average range of soaking time was 12-15.5 $\mathrm{h}$ and the most effective fishing hours of the day were identified as late at night, before dawn, and very early in the morning. The depth range was 48-101 m, although the fishing depth changes during the fishing period to adapt to the lobsters' preferences. There were many different opinions regarding catches in terms of abundance or biomass; most fishermen stated that, typically, they catch from 1 to 4 individuals (or 1-2 kg) per deployment, with a maximum of $10-15 \mathrm{~kg}$ per deployment. Additionally, some fishermen did not provide any data regarding their catches. However, it seems that the potential profit is important, since the retail price per kilogram is quite high at EUR 60-90, but one individual stated that the price can reach as much as $120 \mathrm{EUR} / \mathrm{kg}^{-1}$ (Table 2). The main targeted caught species, associated with spiny lobster fisher, can be as many as 16 species (Table 3).

\subsection{Morphometrics}

In total, 79 spiny lobsters were sampled in this study-49 males (62\%) and 30 females (38\%). In terms of size, $33.3 \%$ of the males and $41.9 \%$ of the females were classified as undersized (their weight was below the legal size of $420 \mathrm{~g}$ ), and two females were ovigerous. This population significantly diverts from the null hypothesis of $1: 1\left(\chi^{2}=4.57 ; p<0.05\right)$, and males are dominant at a ratio of 1.63:1. No significant differences were observed between the sexes regarding morphometric characters, except the abdominal width (Table 4).

Table 4. The values of Student's two-sample $t$-tests, comparing all characteristics between sexes.

\begin{tabular}{cccc}
\hline Characteristic & $\boldsymbol{t}$-Value & $p$-Value & Significance \\
\hline CW & -1.41 & $p=0.043$ & NS \\
CL & 0.82 & $p=0.037$ & NS \\
ABW & -1.91 & $p=0.062$ & S \\
ABL & -0.87 & $p=0.033$ & NS \\
W & -0.002 & $p=0.038$ & NS \\
\hline
\end{tabular}

NS, non-significant; S, significant. 
The maximum, average, and minimum values of all obtained measurements (i.e., CL, CW, ABL, $\mathrm{ABW}$, and W) from the sampling procedure are presented as box plots, since these diagrams offer better clarity (Figure 2) - please see Tables A1-A3 at the Appendix A for further details.

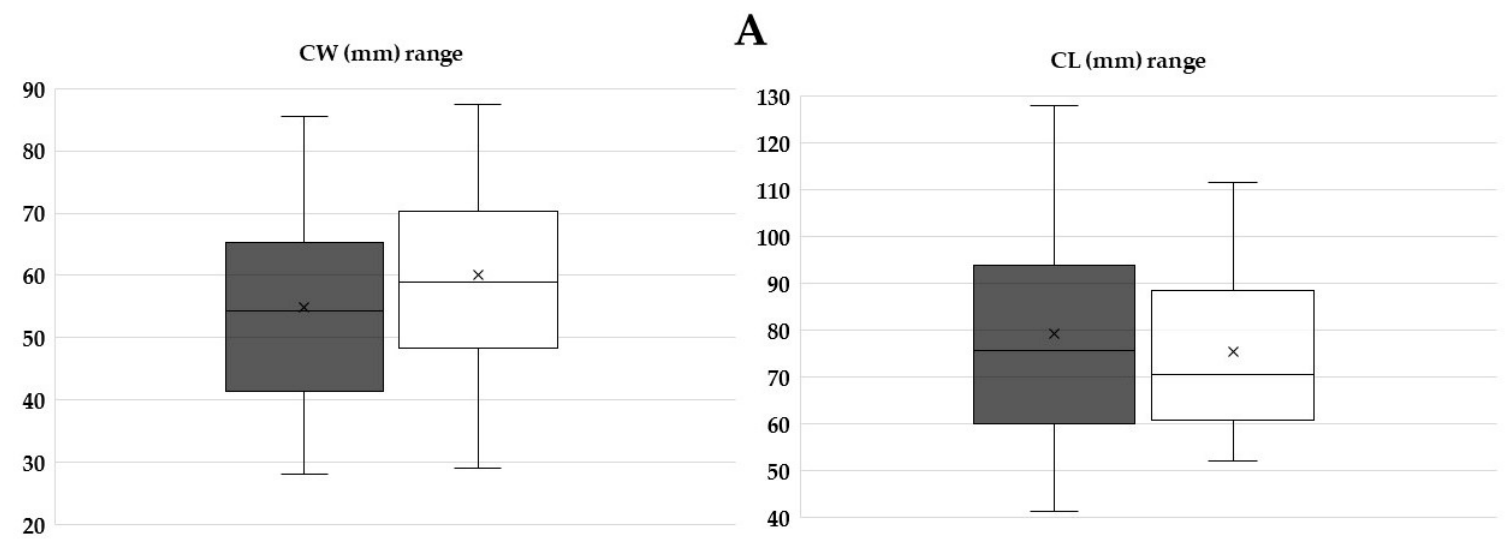

\section{B}
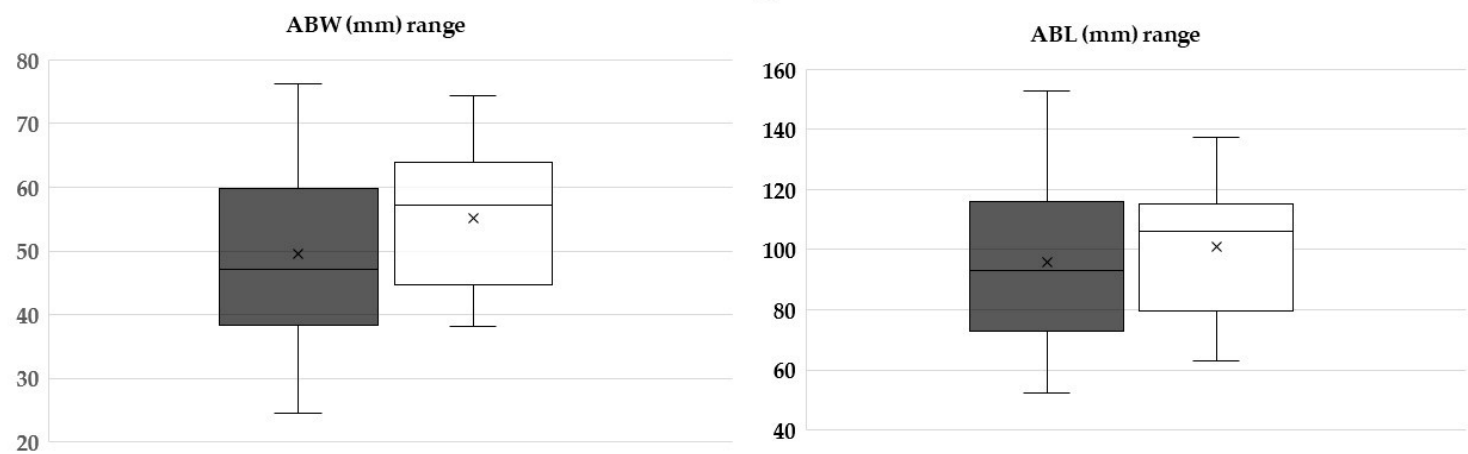

$\mathrm{W}$ (g) range

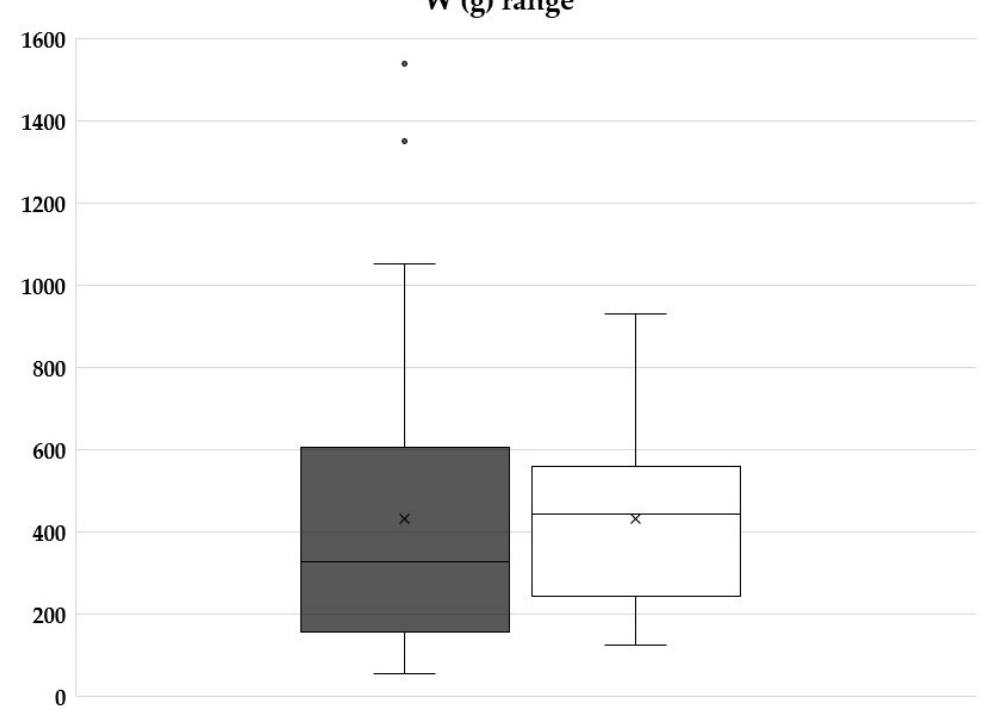

Figure 2. The maximum, average, and minimum values of males (M; black box) and females (F; white box) from the sampling procedure. (A) CW and CL; (B) ABW and ABL; and (C) W. 
All of the morphometric relationships of both males and females demonstrate negative allometric growth profiles (Table 5) of the spiny lobsters in the area, while no significant differences were observed between the sexes. The ranges of $\mathrm{CL} / \mathrm{CW}, \mathrm{ABL} / \mathrm{ABL}$, and $\mathrm{W}$ cover many different size classes.

Table 5. CL-W, carapace width (CW)-W, abdomen length (ABL)-W, and abdomen width (ABW)-W relationship parameters, after log-transformation of the Thermaikos Gulf spiny lobsters (2017).

\begin{tabular}{ccccccc}
\hline \multirow{2}{*}{ Sex } & \multicolumn{3}{c}{ CL-W Parameters } & \multicolumn{3}{c}{ CW-W Parameters } \\
\cline { 2 - 7 } & $\boldsymbol{a}$ & $\boldsymbol{b}$ & $\boldsymbol{r}^{\mathbf{2}}$ & $\boldsymbol{a}$ & $\boldsymbol{b}$ & $\boldsymbol{r}^{\mathbf{2}}$ \\
\hline Males & -6.24 & 2.77 & 0.91 & -5.49 & 2.83 & 0.99 \\
Females & -2.55 & 1.97 & 0.6 & -1.34 & 1.79 & 0.75 \\
\hline \multicolumn{3}{c}{ ABL-W Parameters } & \multicolumn{3}{c}{ ABW-W Parameters } \\
\hline Males & -6.69 & 2.75 & 0.9 & -4.43 & 2.63 & 0.94 \\
Females & -5.1 & 2.4 & 0.9 & -4.8 & 2.69 & 0.89 \\
\hline
\end{tabular}

The distribution of size of the male and female spiny lobsters from the study area is presented in Figure 3. Male spiny lobsters demonstrated a wider size distribution compared to females. There are two main groups regarding males and CL-one in the class size of 50-79 $\mathrm{mm}$, and a second in the 80-89 mm class size (Figure 3A). Meanwhile, there is only one dominant group size of male CW, i.e., in the class size of 40-69 mm (Figure 3B). Male lobsters show two different main groups of ABL-one in the class size of 70-79 $\mathrm{mm}$, and a second in the 90-119 mm class size (Figure 3C). However, there is no specific pattern regarding the ABW frequency distribution in either males or females (Figure 3D). The CL-W relationships for both male and female lobsters are presented in Figure 4, and the CW-W relationships are presented in Figure 5. Meanwhile, Figures 6 and 7 present the ABL-W and ABW-W relationships for both sexes, respectively.
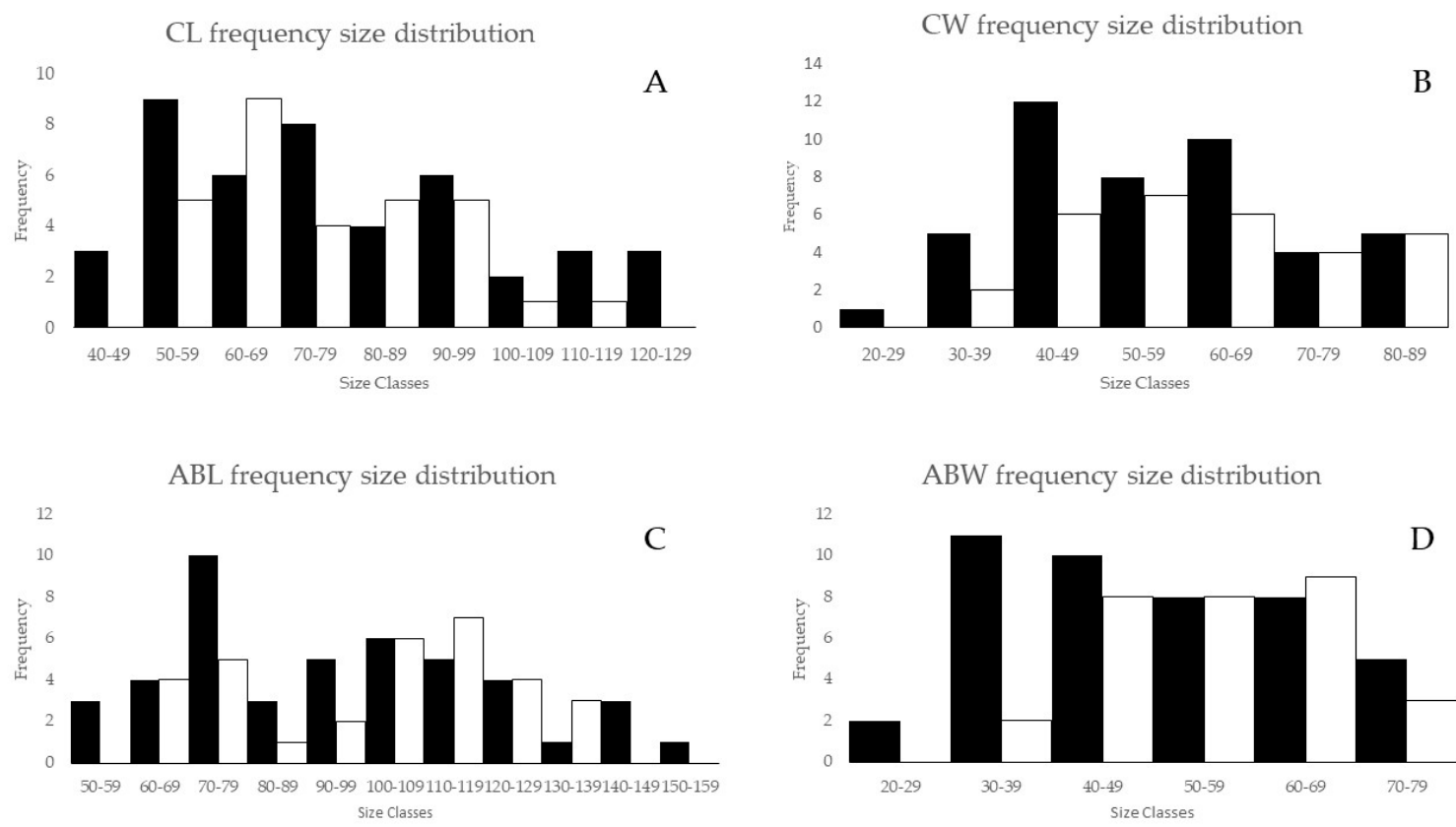

Figure 3. Frequency size distribution of male (black) and female (white) spiny lobsters. (A) CL distribution; (B) CW distribution; (C) ABL distribution; (D) ABW distribution. 


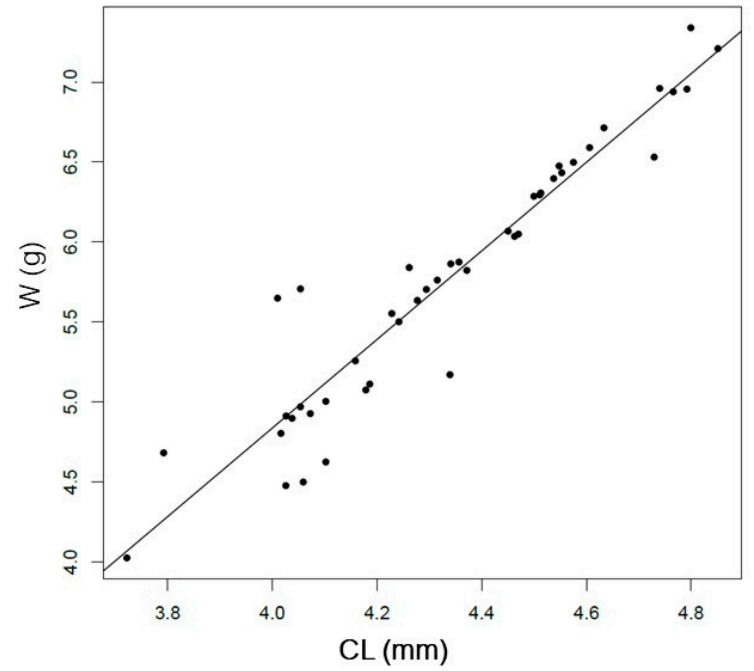

$\mathrm{W}=0.46^{*} \mathrm{CL}^{2.77} \cdot \mathrm{r}^{2}=0.91$

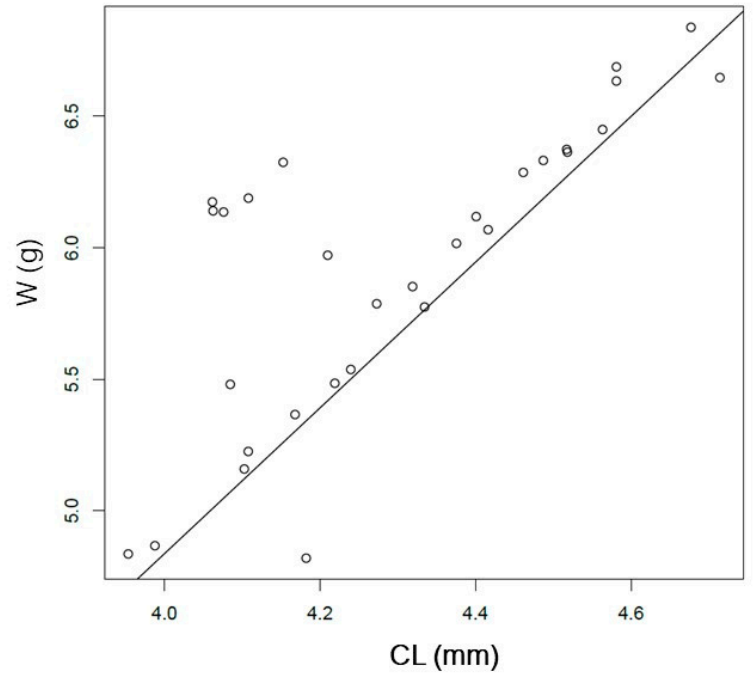

$W=4.15^{*} C^{1.97}, r^{2}=0.6$

Figure 4. Relationship between carapace length (CL) and weight (W) of the male (left) and female (right) spiny lobsters Panilurus elephas from the Thermaikos Gulf. The linear regression was performed and plotted with R. Data presented after log-transformation.

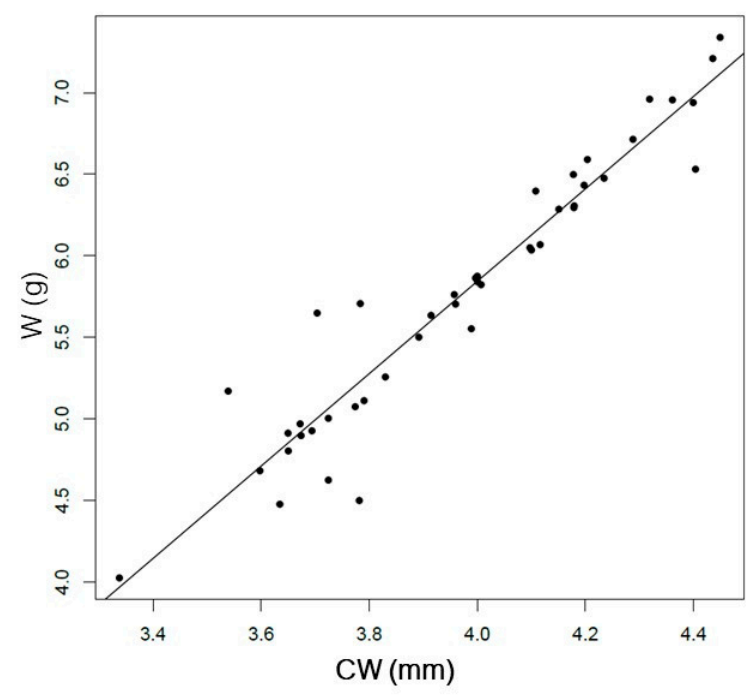

$W=1.21^{*} \mathrm{CL}^{2.83}, \mathrm{r}^{2}=0.99$

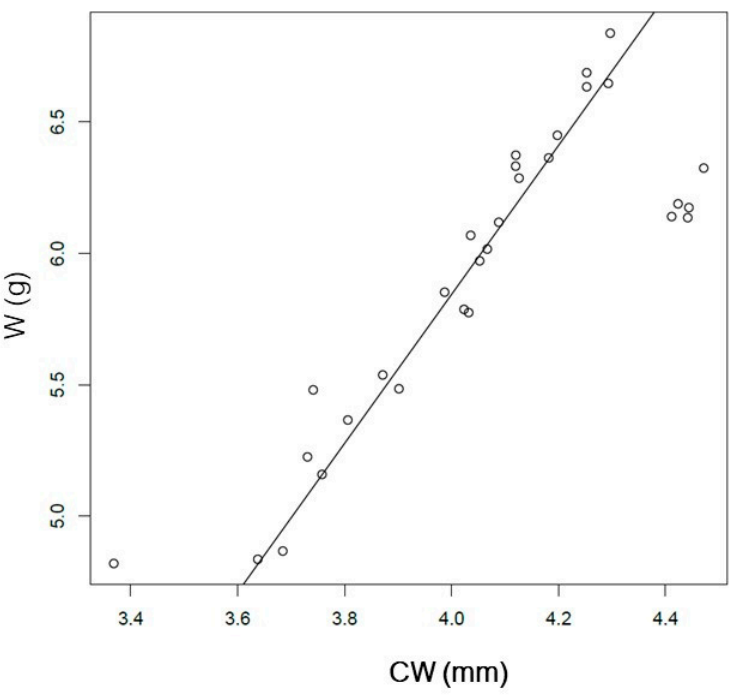

$W=5.36 * L^{1}{ }^{1.79}, r^{2}=0.75$

Figure 5. Relationship between carapace width (CW) and weight $(\mathrm{W})$ of the male (left) and female (right) spiny lobsters Panilurus elephas from the Thermaikos Gulf. The linear regression was performed and plotted with R. Data presented after log-transformation. 


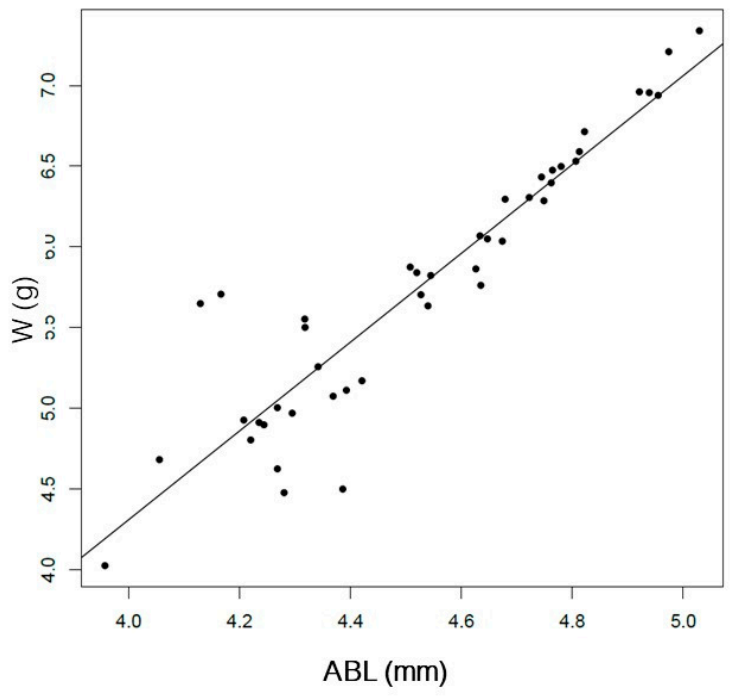

$\mathrm{W}=0.01{ }^{*} \mathrm{CL}^{2.75}, \mathrm{r}^{2}=0.9$

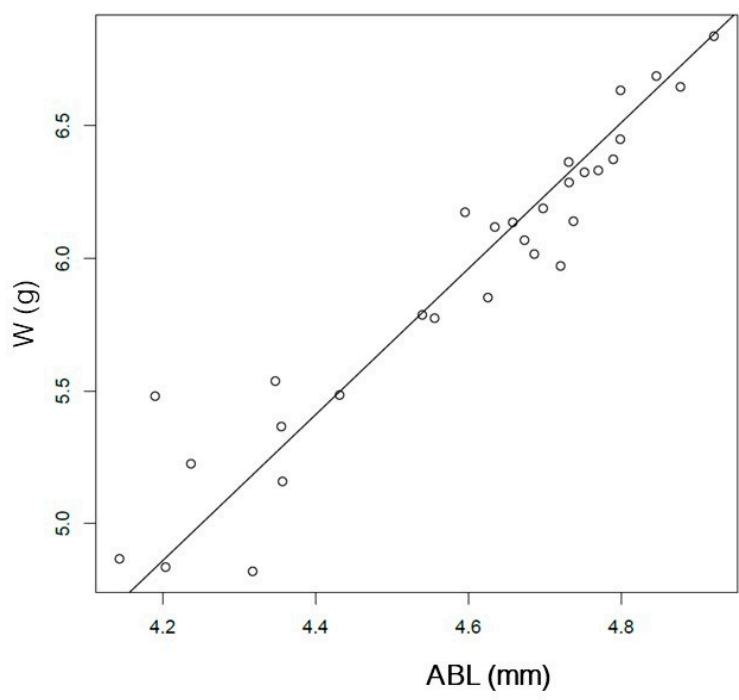

$W=1.6^{*} C^{2} \cdot 2 ., r^{2}=0.9$

Figure 6. Relationship between abdominal length (ABL) and weight (W) of the male (left) and female (right) spiny lobsters Panilurus elephas from the Thermaikos Gulf. The linear regression was performed and plotted with R. Data presented after log-transformation.

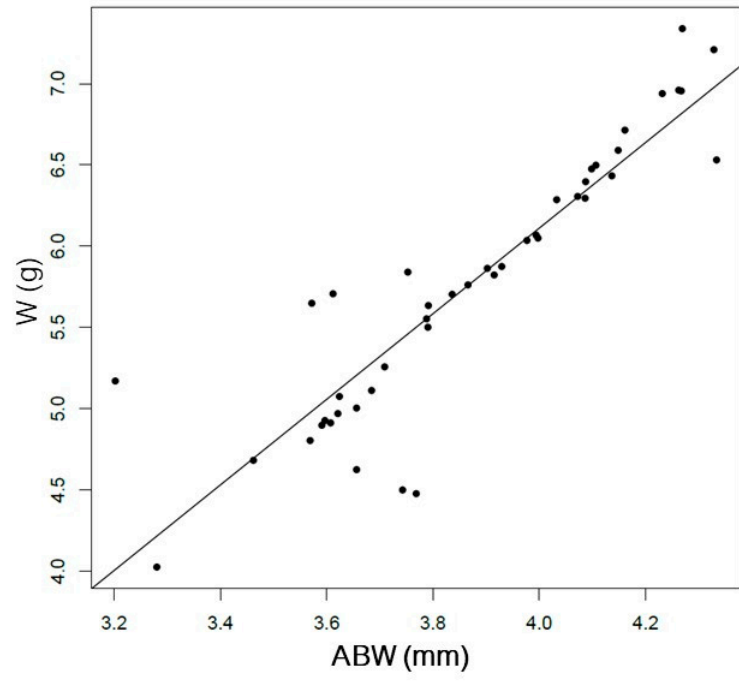

$W=2.27^{\star} C L^{2.63}, r^{2}=0.9$

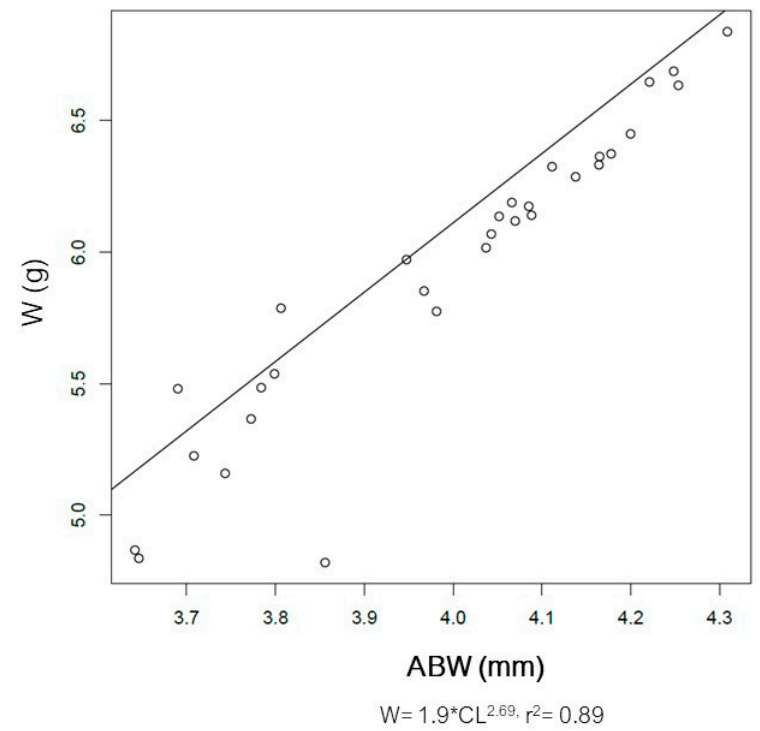

$W=1.9^{*} \mathrm{CL}^{2.69}, \mathrm{r}^{2}=0.89$

Figure 7. Relationship between abdominal width $(\mathrm{ABW})$ and weight $(\mathrm{W})$ of the male (left) and female (right) spiny lobsters Panilurus elephas from the Thermaikos Gulf. The linear regression was performed and plotted with R. Data presented after log-transformation.

\section{Discussion}

This spiny lobster species is not well-studied, and most of the relative data refer to the western Mediterranean Sea [1,20]. Quantitative published data from the eastern Mediterranean Sea are almost lacking, except for the work of Beltrano et al., 2002 [28]. Therefore, studies such as ours are needed in order to understand the biological and ecological requirements of the species, as well as to understand the impacts of anthropogenic pressures such as fisheries, especially for a threatened species such as the European spiny lobster.

During the surveys of the present study, all live and undersized spiny lobsters were released right after obtaining the necessary measurements (which took 1-3 min/lobster). Most individuals showed a remarkable recovery, exhibiting high vitality signs, such as antennae rasping and tail movements, satisfying the criteria described by Mallol et al., 2011 [55]. The results of the present study, related 
to the allometric profile of the spiny lobster, are in accordance (negative allometry) with previous studies, either from the Atlantic Ocean (e.g., [11,14], including the references therein, and [20,22]), or from the Mediterranean Sea (e.g., [20], including the references therein, and [51]). However, a number of the aforementioned studies presented some data very close to isometry $(b=3)[20,50]$. On other occasions, earlier studies focused on L-L relationships (e.g., [20], including the references therein, and [49]) or used different methodologies [56]. It is noteworthy that none of the previous studies dealt with the ABL-W relationship, though it was used in studies regarding other decapod species [52]. Thus, the current study is the first ever to present such data. The sampling size, though comparatively smaller, is satisfying, since it covers a wide range of sizes in both males and females. For instance, the range of CL in male spiny lobsters was from 41.36 to $127.88 \mathrm{~mm}$, which is roughly three times the minimum. In females, the CL ranged from 52.12 to $111.54 \mathrm{~mm}$, roughly two times the minimum. However, the maximum CL sizes for both males and females were lower than that in previous studies. Studies from the Atlantic coasts in the 1960s-1970s reported bigger sizes in male and female spiny lobsters, with a minimum of approximately $58 \mathrm{~mm}$ and a maximum $185 \mathrm{~mm}$ (e.g., [20], including the references therein). Additionally, studies from the Mediterranean Sea in the 1990s-early 2000s, off Britany, Tunisia, and the Columbretes Islands, also reported bigger CL sizes (see [20] for details). The present study presents similarities regarding the average CL with a study from the Sardinian coast [50]. Lastly, the present findings suggest that males may have higher capture probabilities in comparison to female spiny lobsters. This could be linked to the species movement during the night, which is usually associated either with foraging or reproduction [20]; however, the sample size was relatively small and generalizations at the population level should be avoided at the present time, as further research is required.

The number of known fishermen that are directly active and systematically involved at the regional lobster fishery is small. The number of successful interviews, though low, represents $67 \%$ of the total, based on the data of the present study (see Figure 1). Besides the spiny lobster fishery, the participants were asked questions related to general issues, concerns, and management proposals of the artisanal fishery and the lobster fishery in the region. All fishermen indicated that the lobster stock-both spiny and clawed lobsters-declined significantly during the late 1980s and early 1990s, later than most cases in the Mediterranean Sea. According to the fishermen, the landings were as much as 10 times that of the present status, but some caution is required; however, these are the only available regional data. All fishermen identified as a major threat the interaction with dolphins, since they cause heavy and extensive damage to their gear (i.e., nets and long lines), being in accordance with a previous study [57]. Additionally, most fishermen (7/8) raised concerns about the import of fish and shellfish (frozen and fresh) from foreign countries, including live American lobsters (H. americanus). Additionally, 50\% (4/8) of the interviewees, all young fishermen ( $\leq 45$ years), blamed themselves and their ancestors for the present status of overharvested stocks. Lastly, young fishermen expressed their willingness to establish further regional management regulations and better enforcement regarding the lobster (P. elephas and H. gammarus) fishery and proposed various measures, yet they were against at the creation of an MPA (Marine Protected Area) in the area. Their management proposal was driven by their willingness to ensure the sustainability of the lobster fishery, and their suggestions were to: (1) legalize the use of nets (either gill, tangle, or trammel) with a mesh size of $30 \mathrm{~mm}$ from knot to knot; (2) alter the fishery prohibition period from 1 September to mid-August, since berried females are constantly observed in the region; and (3) improve enforcement efforts. Moreover, those who use lobster traps and creels suggested the re-introduction of suchlike gear and the total prohibition of net use, but most of them (6/8) were against net banning, since they were not familiar with the use of other gear.

Further management implications at the regional level should consider the characteristics of regional fishery such as the gear used, conflicts with other users, and environmental protection. Based on the present findings, the spiny lobster, along with H. gammarus, should be considered as a targeted species and not as a by-catch. Considering that most fishermen in the region use nets, larger mesh sizes of at least $50 \mathrm{~mm}$ (knot to knot) should be used, since many undersized individuals were caught during 
the sampling effort of the present study. In addition, further modifications to reduce by-catch with the use of a guarding net [58] should be tested and evaluated in situ, since, in other small-scale prawn (Penaeus kerathurus) fisheries in the Ligurian Sea, some biomass losses have been observed [59]. Lobster traps, modified with escapes gaps that increase selectivity in lobster size [60], will need to be evaluated in situ, and if proven successful, they should progressively replace nets. In agreement with earlier studies, the EU Landing Obligation should exclude spiny lobsters, since they are under threat [58].

Spiny lobsters, and lobsters in general, play an important role in humanity. For example, lobster use is present in many different forms of artifacts, writings, and artwork. Additionally, it is acknowledged that they were a valuable resource for the ancient Greeks and Romans, as both peoples had a remarkable state of knowledge of the biology of lobsters, etc. Furthermore, many indigenous societies across the globe utilize lobsters in many ways [61]. More importantly, they support important independent or multispecies fisheries globally. In addition, since they act as both prey and predators, they have a great contribution to the function, structure, and dynamics of the ecosystem. Spiny lobsters such as P. elephas have been identified as keystone species [62] in many ecosystems worldwide. For instance, in Mexico, lobsters have wreaked large changes on ecosystem structure as keystone predators [63]. Meanwhile, in New Zealand, spiny lobsters were the main factor impacting the presence of sea urchins [64]. Moreover, in Brazil, alterations in the abundance of spiny lobster by the gillnet spiny lobster fishery has posed a serious ecological imbalance, since the four lobster species have an important predatory role within the reef ecosystem, as well as being natural prey for several second-level consumers, such as reef fish species [65]. Lobsters fulfil the most important requirements of being characterized as ecosystem indicators, since they quantify wider environmental changes and their monitoring is essential [66]. Furthermore, the actual lobster landings may be several times more than reported ones, and fishermen interviews can contribute to the re-evaluation of fishing pressure, as demonstrated in other studies [67]. The actual number of catches of threatened marine resources could be several times higher than the official data. For instance, in Norway, it was observed that European lobster catches are as much as 14-fold when compared to official national data [68], which could prove unreliable (e.g., scalloped spiny lobster fishery) [69].

In Greece, thus far, the knowledge and information are sporadic, limited, and/or species-specific, most of which regard finfish fisheries [70]. There are limited published data on decapod fisheries, mainly regarding the Norway lobster, and most of the time, there are no data regarding the spiny lobster fishery biology (e.g., [71]). Therefore, studies such as the present one are quite useful. Furthermore, the national legislation is rather complicated or too generalized, creating great uncertainties regarding the effectiveness of fishery management [72]. It is noteworthy that P. elephas and its habitat are priority conservation features in many Mediterranean and EU counties. The Barcelona and OSPAR convections, signed by European countries including Greece, set specific priorities on the insurance of sustainable management regarding marine resources. Additionally, the EU Common Fisheries policy prioritizes the conservation of marine resources and the warranty of engagement in a profitable fishing sector by wider stakeholders', such as fishers, engagement. In other regions of the world, the fishermen's knowledge and in-depth experience have proven more than useful [43]. The associated ecosystems support an important biodiversity with threatened, economically important, and protected species such as the red coral, gorgonians, groupers, sponges, and the triton (Charonia tritonis). Furthermore, some of the spiny lobster habitats are listed among the threatened EU marine habitats [73] and almost all of them offer many different services, besides fisheries, to humans. These include, amongst others, recreational and tourism services (SCUBA diving), as well as ecological and biodiversity services, since they are biodiversity hotspots. Over and above, these ecosystems are heavily impacted by many threats, such as fishing, directly and indirectly (e.g., ghost fishing), habitat degradation, pollution, alien and invasive species [74], and, of course, climate change, whose impacts are rather unknown, both in terms of biodiversity and fisheries management. 
The in-depth knowledge and experience of fishers have been recognized as a valuable source of scientific information and should be further acknowledged and utilized. Wider collaborations among scientists, practitioners, and policymakers should be further established [75].

European spiny lobsters and the relative fishery requires specific regulations and management that is acknowledged by the fishermen, at least in the study area, based on a three-axial basis: (1) regional conservation and protection of the species and habitats; (2) sustainable fishery management, keeping in mind livelihoods and welfare, with the active involvement of fishermen and other stake holders; and (3) the dissemination of recent trends in fisheries sciences, all of which are top priorities of the European Blue Growth strategy.

Author Contributions: T.E.K. and I.E.B. conceived the study. T.E.K. performed the sampling. T.E.K. and D.M. ran the statistical analyses. T.E.K., D.K., and I.E.B. wrote the manuscript. G.E. and S.T. organized the questionnaires and arranged the interviews. T.E.K. conducted the interviews. D.K. and I.E.B. supervised the study. All authors have read and agreed to the published version of the manuscript.

Funding: This research did not receive any specific grant from funding agencies in the public, commercial, or not-for-profit sectors.

Acknowledgments: All authors are grateful to Dimitris and Kyriakos Ganigiannis, who offered their vessel and fishing gear in kind, thus massively contributing to the present study. The authors also wish to thank all the fishermen that participated in the questionnaires and interviews and, essentially, provided important knowledge regarding regional spiny lobster fishery. Lastly, the authors would like to thank the two anonymous reviewers for all of their comments that contributed to the improvement of this manuscript.

Conflicts of Interest: The authors declare that they have no competing interests.

\section{Appendix A}

Table A1. Minimum, median, average and maximum values of CW and CL regarding the spiny lobsters' measurements, from the Thermaikos Gulf, 2017.

\begin{tabular}{ccccc}
\hline & $\mathbf{C W}(\mathbf{m m}) \mathbf{( M )}$ & $\mathbf{C W}(\mathbf{m m}) \mathbf{( F )}$ & $\mathbf{C L}(\mathbf{m m}) \mathbf{( M )}$ & $\mathbf{C L}(\mathbf{m m}) \mathbf{( F )}$ \\
\hline Minimum & 28.16 & 29.03 & 41.36 & 52.12 \\
Q1 & 41.45 & 48 & 60.04 & 60.82 \\
Median & 54.21 & 59.00 & 75.75 & 70.57 \\
Q3 & 65.29 & 70.29 & 93.70 & 88.32 \\
Maximum & 85.55 & 87.48 & 127.88 & 111.54 \\
Mean & 54.97 & 60.06 & 79.15 & 75.24 \\
Range & 57.39 & 58.45 & 86.52 & 59.42 \\
\hline
\end{tabular}

Table A2. Minimum, median, average and maximum values of ABW and ABL regarding the spiny lobsters' measurements, from the Thermaikos Gulf, 2017.

\begin{tabular}{ccccc}
\hline & ABW $(\mathbf{m m}) \mathbf{( M )}$ & ABW $(\mathbf{m m}) \mathbf{( F )}$ & ABL $(\mathbf{m m}) \mathbf{( M )}$ & ABL $(\mathbf{m m}) \mathbf{( F )}$ \\
\hline Minimum & 24.59 & 38.16 & 52.31 & 63.02 \\
Q1 & 38.41 & 44.73 & 73.06 & 79.52 \\
Median & 47.05 & 57.25 & 93.07 & 106.27 \\
Q3 & 59.75 & 63.92 & 115.83 & 115.41 \\
Maximum & 76.22 & 74.35 & 152.79 & 137.2 \\
Mean & 49.58 & 55.22 & 95.92 & 100.90 \\
Range & 51.63 & 36.19 & 100.48 & 74.18 \\
\hline
\end{tabular}


Table A3. Minimum, median, average and maximum values of $\mathrm{W}$ regarding the spiny lobsters' measurements, from the Thermaikos Gulf, 2017.

\begin{tabular}{ccc}
\hline & W $(\mathrm{g})(\mathbf{M})$ & W $(\mathrm{g})(\mathrm{F})$ \\
\hline Minimum & 56 & 124 \\
Q1 & 157.25 & 244.25 \\
Median & 328.00 & 443.00 \\
Q3 & 605.50 & 561.00 \\
Maximum & 1539 & 932 \\
Mean & 432.66 & 432.83 \\
Range & 1483 & 808 \\
\hline
\end{tabular}

\section{References}

1. Groeneveld, J.C.; Goñi, R.; Díaz, D. Palinurus species. In Lobsters: Biology, Management, Aquaculture and Fisheries, 2nd ed.; Phillips, B.F., Ed.; Wiley-Blackwell: Oxford, UK, 2013; pp. 326-356.

2. Cockcroft, A.; Butler, M.; MacDiarmid, A. Palinurus charlestoni. Available online: https://www.iucnredlist. org/species/170046/6720146 (accessed on 3 June 2019).

3. Cockcroft, A.; Butler, M.; MacDiarmid, A. Palinurus mauritanicus. Available online: https://www.iucnredlist. org/species/170035/6715683 (accessed on 3 June 2019).

4. Goñi, R. Palinurus elephas. Available online: https://www.iucnredlist.org/species/169975/1281221 (accessed on 3 June 2019).

5. Froglia, C.; Silvestri, R.; Serena, F. First record of Panulirus regius (Decapoda: Palinuridae) in the Italian seas, with remarks on the earlier Mediterranean records. Mar. Biodivers. Rec. 2012, 5, e31. [CrossRef]

6. Pavičić, M.; Dragičević, B.; Žužul, I.; Vrdoljak, D.; Matić-Skoko, S.; Šegvić-Bubić, T. First record of American lobster, Homarus americanus (H. Milne Edwards, 1837), in the Mediterranean Sea. BioInvasions Rec. 2020, 9 , 83-88. [CrossRef]

7. Galil, B.; Pisanty, S.; Spanier, E.; Tom, M. The Indo-Pacific lobster Panulirus ornatus (Crustacea: Decapoda): A new Lessepsian migrant to the eastern Mediterranean. Isr. J. Zool. 1989, 35, 241-243.

8. Wilson, E. Spiny Lobsters off the Scottish coast. Scott. Nat. 1954, 66, 121-122.

9. Holthuis, L.B. Marine lobsters of the world. An Annotated and Illustrated Catalogue of Species of Interest to Fisheries Known to date. FAO Fish. Synop. 1991, 13, 25.

10. Ritchie, J. On the Distribution of the Thorny Lobster (Palinurus vulgaris) in British Waters. Proc. R. Soc. Edinburgh. 1910, 18, 68-71.

11. Ansell, A.D.; Robb, L. The spiny lobster Palinurus elephas in Scottish waters. Mar. Biol. 1977, 43, 63-70. [CrossRef]

12. Appellöf, J.J.A. Die Dekapoden Crustaceen. In Meeresfauna von Bergen; Bergens Museum: Bergen, Germany, 1906; pp. 114-233.

13. Selbie, C.M. The Decapoda Reptantia of the Coasts of Ireland. Part I. Palinura, Astacura and Anomura (Except Paguridea). Scientific Investigations; Browne and Nolan Ltd.: London, UK, 1914; p. 272.

14. Hunter, E. Biology of the European spiny lobster, Palinurus elephas (Fabricius, 1787) (Decapoda, Palinuridea). Crustaceana 1999, 72, 545-565. [CrossRef]

15. Giacalone, V.M.; Barausse, A.; Gristina, M.; Pipitone, C.; Visconti, V.; Badalamenti, F.; D’Anna, G. Diel activity and short-distance movement pattern of the European spiny lobster, Palinurus elephas, acoustically tracked. Mar. Ecol. 2015, 36, 389-399. [CrossRef]

16. Minchin, D. A Study of Some Invertebrate Resources within Berrabouy Bay, Connemara; Fishery Leaflet No. 77; Department of Agriculture and Fisheries, Fisheries Division: Dublin, Ireland, 1975; p. 16.

17. Bonnier, J. Catalogue des Crustacés Malacostracés Recueillis dans la baie de Concarneau; Octave Doin: Paris, France, 1887; pp. 53-54.

18. Maldura, L.M. La pesca nelle isole Italiane dell'Egeo. Boll. Pesca Piscic. Idrobiol. 1938, 14, 460-480.

19. Marin, J. La Pêcherie de Langouste Rouge en Corse; Report No. 88.016; Institut Français de Recherche pour l'Exploitation de la Mer: Brest, France, 1985; p. 93.

20. Goñi, R.; Latrouite, D. Review of the biology and fisheries of Palinurus spp. Species of European waters: Palinurus elephas (Fabricius, 1787) and Palinurus mauritanicus (Gruvel, 1911). Cah. Biol. Mar. 2005, 46, 127-142. 
21. Hepper, B.T. The fishery of crawfish, Palinurus elephas, off the coast of Cornwall. J. Mar. Biol. Assoc. UK 1977, 57, 925-941. [CrossRef]

22. Hunter, E.; Shackley, S.E.; Bennett, D.B. Recent studies on the crawfish Palinurus elephas in South Wales and Cornwall. J. Mar. Biol. Assoc. UK 1996, 76, 963-983. [CrossRef]

23. Gristina, M.; Gagliano, M. Performance of traditional rush and modern plastic traps on the capture of Palinurus elephas (Fabricius, 1787) in laboratory tanks. Fish. Res. 2004, 67, 235-239. [CrossRef]

24. Le Manach, F.; Dura, D.; Pere, A.; Riutort, J.J.; Lejeune, P.; Santoni, M.C.; Culioli, J.M.; Pauly, D. Preliminary Estimate of Total Marine Fisheries Catches in Corsica, France (1950-2008). In Fisheries Centre Research Reports 19(4), Fisheries Catch Reconstructions: Islands, Part II; Harper, S., Zeller, D., Eds.; The Fisheries Centre, University of British Columbia: Vancouver, BC, Canada, 2011; pp. 3-14.

25. Goñi, R.; Quetglas, A.; Reňones, O.; Mas, J. Threats to the sustainability of Palinurus elephas fisheries. Lobster Newsl. 2003, 16, 2-5.

26. Moraitoplou-Kasimati, E. Lobster Fishery; Fishery and Holding Alive Methodologies; Advices to Fishermen; Applicable Research Bulletin No.3; Institute of Oceanography and Fisheries Research: Athens, Greece, 1973.

27. Kasimati-Moraitoplou, E. Contribution to the Knowledge of Lobsters (Palinurus Vulgaris and Homarus Vulgaris) in the Greek Seas; Special Publication No.1; Institute of Oceanography and Fisheries Research: Athens, Greece, 1979.

28. Beltrano, A.M.; Cannizzaro, L.; Kallianiotis, A.A.; Bono, G.; Vitale, S.; Potoschi, A.; Milazzo, A.; Vidoris, P. Fishery of the spiny lobster Palinurus elephas (Fabricius, 1787) in Italy and Greece. 2002. In Proceedings of the 8th Colloquium Crustacea Decapoda Mediterranea, Ionian University, Corfu, Greece, 2-6 September 2002.

29. Gönülal, O. Spiny lobster (Palinurus elephas Fabricius, 1787) and Common lobster (Homarus gammarus Linnaeus, 1758) Fishing in the North Aegean Sea. In The State of the Turkish Fisheries; Tokaç, A., Gücü, A.C., Özturk, B., Eds.; Turkish Marine Research Foundation: Istanbul, Turkey, 2012.

30. Josileen, J. Morphometrics and Length-weight relationship in the blue swimmer crab, Portunus pelagicus (Linnaeus, 1758) (Decapoda, Brachyura) from the Mandapam coast, India. Crustaceana 2011, 84, 1665-1681. [CrossRef]

31. Martínez-Calderón, R.; Lozano-Álvarez, E.; Briones-Fourzán, P. Morphometric relationships and seasonal variation in size, weight, and a condition index of post-settlement stages of the Caribbean spiny lobster. PeerJ 2018, 6, e5297. [CrossRef]

32. Maguire, I.; Marn, N.; Klobučar, G. Morphological evidence for hidden diversity in the threatened stone crayfish Austropotamobius torrentium (Schrank, 1803) (Decapoda: Astacoidea: Astacidae) in Croatia. J. Crustacean Biol. 2017, 37, 7-15. [CrossRef]

33. Zheng, J.; Murphy, M.C.; Kruse, G.H. A length-based population model and stock-recruitment relationships for red king crab, Paralithodes camtschaticus, in Bristol Bay, Alaska. Can. J. Fish. Aquat. Sci. 1995, 52, 1229-1246. [CrossRef]

34. Herter, H.; Daly, B.; Swingle, J.S.; Lean, C. Morphometrics, fecundity and hatch timing of the blue King crabs (Paralithodes platypus) from the Bering Strait, Alaska, USA. J. Crustacean Biol. 2011, 31, 304-312. [CrossRef]

35. Brash, J.M.; Cook, R.L.; Mackenzie, C.L.; Sanderson, W.G. The demographics and morphometries of biogenic reefs: Important considerations in conservation management. J. Mar. Biol. Assoc. UK 2017, 98, 1231-1240. [CrossRef]

36. Sakellariou, D.; Alexandri, M. Geomorphology of the Hellenic Sea-Floor. In State of Hellenic Fisheries; Papaconstantinou, C., Zenetos, A., Vassilopoulou, V., Tserpes, G., Eds.; HCMR Publications: Athens, Greece, 2007; pp. 17-23.

37. Stergiou, K.I.; Christou, E.D.; Georgopoulos, D.; Zenetos, A.; Souvermezoglou, C. The Hellenic seas: Physics, chemistry, biology and fisheries. Oceanogr. Mar. Biol. 1997, 35, 415-538.

38. Krestenitis, Y.N.; Kombiadou, K.D.; Androulakis, Y.S. Interannual variability of the physical characteristics of North Thermaikos Gulf (NW Aegean Sea). J. Mar. Syst. 2012, 96, 132-151. [CrossRef]

39. Tragou, E.; Zervakis, V.; Papageorgiou, E.; Stavrakakis, S.; Lykousis, V. Monitoring the physical forcing of resuspension events in the Thermaikos Gulf-NW Aegean during 2001-2003. Cont. Shelf Res. 2005, 25, 2315-2331. [CrossRef]

40. Katsikatsou, M.; Anestis, A.; Pörtner, H.O.; Kampouris, T.; Michaelidis, B. Field studies on the relation between the accumulation of heavy metals and metabolic and HSR in the bearded horse mussel Modiolus barbatus. Comp. Biochem. Phys. C 2011, 153, 133-140. [CrossRef] [PubMed] 
41. Thessalou-Legaki, M. Decapod Crustaceans: An Account on Species Occurrence and Exploitation in Hellenic Waters. In State of Hellenic Fisheries; Papaconstantinou, C., Zenetos, A., Vassilopoulou, V., Tserpes, G., Eds.; HCMR Publications: Athens, Greece, 2007; pp. 85-92.

42. Kampouris, T.E.; Porter, J.S.; Sanderson, W.G. Callinectes sapidus Rathbun, 1896 (Brachyura: Portunidae): An assessment on its diet and foraging behaviour, Thermaikos Gulf, NW Aegean Sea, Greece: Evidence for ecological and economic impacts. Crus. Res. 2019, 48, 23-37. [CrossRef]

43. Heyman, W.; Granados-Dieseldorff, P. The voice of the fishermen of the Gulf of Honduras: Improving regional fisheries management through fisher participation. Fish. Res. 2012, 125, 129-148. [CrossRef]

44. Bucaram, S.J.; Hearn, A. Factors that influence the entry-exit decision and intensity of participation of fishing fleet for the Galapagos lobster fishery. Mar. Pol. 2014, 43, 80-88. [CrossRef]

45. Szuwalski, C.S.; Castrejon, M.; Ovando, D.; Chasco, B. An integrated stock assessment for red spiny lobster (Panulirus penicillatus) from the Galapagos Marine Reserve. Fish. Res. 2016, 177, 82-94. [CrossRef]

46. Tewfik, A. The influence of waves on landing patterns within a diverse Sumatran spiny lobster (Panulirus spp.) fishery. N. Z. J. Mar. Fresh. 2014, 48, 245-255. [CrossRef]

47. Pascoe, S.; Coglan, L.; Punt, A.E.; Dichmont, C.M. Impacts of Vessel Capacity Reduction Programmes on Efficiency in Fisheries: The Case of Australia's Multispecies Northern Prawn Fishery. J. Agric. Econ. 2012, 63, 425-443. [CrossRef]

48. Cosgrove, R.; Gosch, M.; Reid, D.; Sheridan, M.; Chopin, N.; Jessopp, M.; Cronin, M. Seal bycatch in gillnet and entangling net fisheries in Irish waters. Fish. Res. 2016, 183, 192-199. [CrossRef]

49. Hepper, B.T. Measurement of carapace length and total length in the crawfish, Palinurus vulgaris. J. Cons. Int. Explor. Mer. 1966, 30, 316-323. [CrossRef]

50. Tidu, C.; Sardá, R.; Pinna, M.; Cannas, A.; Meloni, M.F.; Lecca, E.; Savarino, R. Morphometric relationships of the European spiny lobster Palinurus elephas from northwestern Sardinia. Fish. Res. 2004, 69, 371-379. [CrossRef]

51. Sint, D.; Via, D.; Füreder, L. Morphological variations in Astacus astacus L. and Austropotamobius pallipes (Lereboullet) populations. Bull. Fr. Pêche Piscic. 2005, 376, 637-652. [CrossRef]

52. Kapiris, K.; Conides, A. Studies on the allometric growth of the caramote prawn Melicertus kerathurus (Decapoda, Penaeidae) in Western Greece (E. Mediterranean). Med. Mar. Sci. 2009, 10, 25-34. [CrossRef]

53. Zhang, Z.; Yokota, M.; Strüssmann, C.A. Relative growth pattern and relative condition factor in the Japanese mitten crab Eriocheir japonica (De Haan, 1835) (Brachyura: Varunidae). J. Crustacean Biol. 2017, 37, 571-578. [CrossRef]

54. R Core Team. R: A Language and Environment for Statistical Computing; R Foundation for Statistical Computing: Vienna, Austria, 2016.

55. Mallol, S.; Díaz, D.; Sobrado, F.; Goñi, R. First V-notching experience of a spiny lobster: V-notch recovery and impact on health and growth of Palinurus elephas. Crustaceana 2014, 34, 25-30. [CrossRef]

56. Follesa, M.; Cuccu, D.; Cannas, R.; Cau, A. On the growth of the European spiny lobster Palinurus elephas from Sardinian waters (central western Mediterranean Sea). N. Z. J. Mar. Fresh. 2007, 41, 377-383. [CrossRef]

57. Pardalou, A.; Tsikliras, A.C. Anecdotal information on dolphin-fisheries interactions based on empirical knowledge of fishers in the northeastern Mediterranean Sea. ESEP 2018, 18, 1-8. [CrossRef]

58. Catanese, G.; Hinz, H.; del Mar Gil, M.; Palmer, M.; Breen, M.; Mira, A.; Pastor, E.; Grau, A.; Campos-Candela, A.; Koleva, E.; et al. Comparing the catch composition, profitability and discard survival from different trammel net designs targeting common spiny lobster (Palinurus elephas) in a Mediterranean fishery. PeerJ 2018, 6, e4707. [CrossRef] [PubMed]

59. Sartor, P.; Li Veli, D.; De Carlo, F.; Ligas, A.; Massaro, A.; Musumeci, C.; Sartini, M.; Rossetti, I.; Sbrana, M.; Viva, C. Reducing unwanted catches of trammel nets: Experimental results of the "guarding net" in the caramote prawn, Penaeus kerathurus, small-scale fishery of the Ligurian Sea (western Mediterranean). Sci. Mar. 2018, 82 (Suppl. 1), 131-140. [CrossRef]

60. Broadhursta, M.K.; Millar, R.B. Configuring escape gaps in recreational rectangular traps to improve size selection for eastern rock lobster, Sagmariasus verreauxi. Fish. Res. 2018, 207, 182-186. [CrossRef]

61. Spanier, E.; Lavalli, K.L.; Goldstein, J.S.; Groeneveld, J.C.; Jordaan, G.L.; Jones, C.M.; Phillips, B.F.; Bianchini, M.L.; Kibler, R.D.; Díaz, D.; et al. A concise review of lobster utilization by worldwide human populations from prehistory to the modern era. ICES J. Mar. Sci. 2015, 72 (Suppl. 1), i7-i21. [CrossRef] 
62. Eddy, T.D.; Pitcher, T.J.; MacDiarmid, A.B.; Byfield, T.T.; Tam, J.C.; Jones, T.T.; Bell, J.J.; Gardner, J.P.A. Lobsters as keystone: Only in unfished ecosystems? Ecol. Model. 2014, 275, 48-72. [CrossRef]

63. Castañeda-Fernández-de-Lara, V.; Serviere-Zaragoza, E.; Hernández-Vázquez, S.; Butler, M.J., IV. Feeding ecology of juvenile spiny lobster, Panulirus interruptus, on the Pacific coast of Baja California Sur, Mexico. N. Z. J. Mar. Fresh. 2005, 39, 425-435. [CrossRef]

64. Shears, N.T.; Babcock, R.C. Continuing trophic cascade effects after 25 years of no-take marine reserve protection. Mar. Ecol. Prog. Ser. 2003, 246, 1-16. [CrossRef]

65. Cruz, R.; Silva, K.C.A.; Neves, S.D.S.; Cintra, I.H.A. Impact of lobster size on catches and prediction of commercial spiny lobster landings in Brazil. Crustaceana 2013, 86, 1274-1290. [CrossRef]

66. Rowland, J.A.; Nicholson, E.; Murray, N.J.; Keith, D.A.; Lester, R.E.; Bland, L.M. Selecting and applying indicators of ecosystem collapse for risk assessments. Conserv. Biol. 2018, 32, 1233-1245. [CrossRef]

67. Duplisea, D.E. Fishermen's Historical Knowledge Leads to a Re-Evaluation of Redfish Catch. Mar. Coast. Fish. 2018, 10, 3-11. [CrossRef]

68. Kleiven, A.R.; Olsen, E.M.; Vølstad, J.H. Total catch of a red-listed marine species is an order of magnitude higher than official data. PLoS ONE 2012, 7, e31216. [CrossRef]

69. Al-Marzouqi, A.; Chesalin, M.; Al-Shajibi, S.; Al-Hadabi, A.; Al-Senaidi, R. Changes in the scalloped spiny lobster, Panulirus homarus, biological structure after a shit of the fishing season. JAMB 2015, 3, 00056.

70. Sini, M.; Katsanevakis, S.; Koukourouvli, N.; Gerovasileiou, V.; Dailianis, T.; Buhl-Mortensen, L.; Damalas, D.; Dendrinos, P.; Dimas, X.; Frantzis, A.; et al. Assembling Ecological Pieces to Reconstruct the Conservation Puzzle Aegean Sea. Front. Mar. Sci. 2017, 4, 347. [CrossRef]

71. Tsikliras, A.C.; Tsiros, V.Z.; Stergiou, K.I. Assessing the state of Greek marine fisheries resources. Fish. Manag. Ecol. 2013, 20, 34-41. [CrossRef]

72. Petza, D.; Maina, I.; Koukourouvli, N.; Dimarchopoulos, D.; Akrivos, D.; Kavadas, S.; Tsikliras ACKarachle, P.K.; Katsanevakis, S. Where not to fish-Reviewing and mapping fisheries restricted areas in the Aegean Sea. Med. Mar. Sci. 2017, 18, 310-323. [CrossRef]

73. Gubbay, S.; Sanders, N.; Haynes, T.; Janssen, J.A.M.; Rodwell, J.R.; Nieto, A.; Garcia Criado, M.; Beal, S.; Borg, J.; Kennedy, M.; et al. European Red List of Habitats. Part 1. Marine habitats; Publications Office of the European Union: Luxembourg, 2016.

74. Corsini-Foka, M.; Mastis, S.; Kondylatos, G.; Batjakas, I.E. Alien and native fish in gill nets at Rhodes, eastern Mediterranean (2014-2015). J. Mar. Biol. Assoc. UK 2017, 97, 635-642. [CrossRef]

75. Azzurro, E.; Bolognini, L.; Dragičević, B.; Drakulović, D.; Dulčić, J.; Fanelli, E.; Grati, F.; Kolitari, J.; Lipej, L.; Magaletti, E.; et al. Detecting the occurrence of indigenous and non-indigenous megafauna through fishermen knowledge: A complementary tool to coastal and port surveys. Mar. Pollut. Bull. 2019, 147, 229-236. [CrossRef]

(C) 2020 by the authors. Licensee MDPI, Basel, Switzerland. This article is an open access article distributed under the terms and conditions of the Creative Commons Attribution (CC BY) license (http://creativecommons.org/licenses/by/4.0/). 